\title{
THE NARROW CORNER - WHERE HOMOSEXUALITY HIDES
}

\section{Hélio Dias Furtado*}

Abstract: According to his biographers, W. Somerset Maugham was always careful about not allowing traces of his homosexuality to get into his novels. However, it seems Maugham was not entirely successful in carrying out this decision of his. At least, this is what can be concluded after reading Gore Vidal's "Maugham's Half \& Half where he points out The Narrow Corner, Maugham's novel published in 1932, as one dealing covertly with the homosexuality theme. Our intention is to conduct a careful analysis of this novel to raise its hidden traces of homosexuality which, in Vidal's view, Maugham is not successful in disguise.

Keywords: Maugham; Homosexuality; The Narrow Corner

That W. Somerset Maugham was a homosexual is no secret for those who are familiar with some facts of his private life. Any of his several biographies points out the fact that, although he married once and even had a daughter, he spent most of his life with his male lover, Gerald Haxton, and, after Haxton's death, with Alan Searle. However, another fact that is not always emphasized by his biographers is Maugham's constant preoccupation about keeping out of his fiction any trace of his sexual orientation. ${ }^{1}$ In spite of this, in Maugham's Half 2 Half, the American critic Gore Vidal says that as early as 1948, he and his also homosexual friend Tennessee Williams chose The Narron' Corner, Maugham's novel published in 1932, as one of the novels they had so far read that dealt, overtly or covertly, with same-sex sexuality (Vidal, 1991). For an inattentive reader doing a superficial reading, this novel has no obvious elements which indicate the treatment of male homosexuality as one of its themes. However, a lormer lecturer at l'aculdade de lectras/ Universidade licderal de Alagoas, now working at Universidade
licederal do Rio Girande do Norte.

In example of this preoccupation is given by one of his biographers, Robert lorin Calder, in II: Somered Maughlum and the (2uest for Freedum (London: William I lcinemann Ltd., 1972), p. 25. Ile says:

"The laws concerning homosexuality during most of Maugham 's life and his concern for his public reputation, hewever, prevented him from crer treating the subject. I lis attitude is reflected in the advee which he gare his nephew about the publication of Robin 's homosexual book, T\%e Wrone People: My uncle said. "I 'm gong to perur you a particularly large martini, because you're going to need it. Yours is the only book tere taken to bed and had te read right through to the end. But I thenk it will kill you stone dead as a writer. They will murder you." Then my uncle said that various details would imply that at some stage in my life I must have had some experience of homosexuality, and that would be bad for my public". 
more careful reading will show that, as Vidal suggests, it has some aspects which deal, most of the time in a covert way, with that theme.

In searching for hidden traces of homosexuality in The Narrow Corner, the first element which draws one's attention is the mystery involving its protagonist, Dr. Saunders. Dr. Saunders is an Englishman who lives in a small Chinese island called Fu-chou. Although there is a small community of English people living in this same Island, they have no social contact with him unless when their own "English doctor" is away on leave. The reason, we are told, is that they disapprove of his association with the native inhabitants of that place. Besides, they also disapprove of his consumption of opium. This situation characterizes Dr. Saunders as someone excluded not only from the geographical boundaries of the English society, but also from its moral boundaries, an exclusion which extends even to a small community of English citizens far away from Britain such as Fu-chou.

With the appearance of another character in the story, Captain Nichols, suspicions are raised about the reason of his living in Fu-chou. At least in two conversations, Captain Nichols keeps raising questions about Dr. Saunders's leaving his country to live by himself in such a distant place. In his view, had he stayed in his country he could be now famous, rich, and even hold a baronet. So, Captain Nichol's questions are always fraught with suspicions about what might have led the English doctor to make such a decision. However, the latter is never intimidated by the Captain's insinuations and always remains indifferent to his speculations.

In spite of raising so much suspicion about Dr. Saunders's past life, no answer is given to it by the narrator. The story ends and, as readers, we are not allowed to know what in fact motivated Dr. Saunders's decision. So, some questions remain to be answered: Why did he leave England to live in such a desolate place? What is such a mystery that cannot be revealed? And what is Maugham's intention in not telling it to his readers? Perhaps the answer to these questions lies outside the story. If we assume that Dr. Saunders is homosexual, as an English man he certainly had strong reasons for leaving his country. In the history of the persecution against the homosexual in England, Collin Spencer reports the several moments in which, afraid of having their own physical and moral integrity violated, many homosexuals crossed the English Channel in the direction of either France or Italy where they could find more tolerance to their sexuality (Spencer, 1996). During Maugham's youth, England witnessed Oscar Wilde's conviction when, according to Ted Morgan "the boat train to Calais 
was packed with homosexual émigrés. They left for Paris and Nice, Naples and Capri, Palermo and Seville, anyplace where they felt safe from prosecution" (Morgan, 1980). Thus, his homosexuality explains not only Dr. Saunders's departure from his homeland but it also explains his detachment from his countrymen even while in Fu-chou.

This answer to Dr. Saunders's mystery is just a supposition. There is no clear evidence in the story which points out to homosexuality as the reason for his leaving England. However, it is not a supposition his evident fondness of male beauty. For two male characters in the story he expresses his admiration of their beauty. They are Ah Kay, his Chinese servant and Fred Blake, the Australian young man whom he joins in a boat to get a ride to another island. It is in the very beginning of the story that the narrator gives us a description of Ah Kay through the eyes of Dr. Saunders. He is described as a comely youth whose face has a symmetrical beauty. Describing his body's movements, the narrator says that "he moved silently and his gestures had the deliberate grace of a cat". ${ }^{2}$ Suggestively, this paragraph of description ends with the narrator asserting that "Dr. Saunders sometimes flattered himself with the thought that Ah Kay regarded him with affection" (Narrow, 37). To come to the conclusion, based on such an assertion, that there is any kind of emotional or even sexual relationship between Dr. Saunders and his Chinese servant is extremely cursory. However, it is evident that the doctor's satisfaction with him goes beyond the performances of his duties. At least his beautiful face makes him a pleasure to the doctor's eyes.

If Ah Kay's description is not that significant in terms of a homoerotic reading of The Narrow Corner, Dr. Saunders's reaction and admiration of Fred Blake's beauty does not go unnoticed. Although never mentioned overtly, there are clear indications that he is deeply disturbed by it since their first encounter. After this first meeting in which Captain Nichols is also present, the doctor is unable to rest. More than once he tries to take a nap after meal, but the two strangers keep disturbing his mind. Actually, we are told that it is Fred that keeps disturbing him the most. The doctor could well place the captain within his own categorization of human beings. However, there is something in Fred he cannot deal with and that makes him completely unrest. The reason he gives for this restlessness is that as an educated young man Fred did not fit in that situation, i.e., in a partnership with a scoundrel like Captain Nichols.

W. Somerset Maugham, The Narron Corner (Middlessex: Penguin Book Ltd, 1967), p. 37. Further citations from this novel will be given in the text as Narrow and the page number. 
However, this explanation does not agree with the description of Dr. Saunders's personality that is presented soon after. According to the narrator, he is someone who

took an interest in his fellows that was not quite scientific and not quite human. He wanted to receive entertainment from them. He regarded them dispassionately and it gave him just the same amusement to unravel the intricacies of the individual as a mathematician might find in the solution of a problem (Narrow, 24).

In other words, it is a trace of his personality to hold a certain aloofness and indifferent attitude towards human beings. In the light of such a description, the peculiar restlessness of Dr. Saunders's on account of Fred becomes quite significant for two reasons. First of all, he could not keep his usual aloofness. Besides, as we find out later, he does not have a similar reaction to the other Europeans he meets in those distant islands.

Actually, what moves Dr. Saunders so deeply is really Fred's physical beauty. A disguised apology of male beauty is a theme that permeates the whole novel. At a first moment, the treatment of this theme in The Narron Corner reminds us of the Romantic rediscovery of the body, especially the male body, in a classical perspective contrasting to a Christian one, as it is pointed out by Eve Sedgwick in Epistemology of the Closet (Sedgwick, 1994). However, as the story develops we see that any "unphobic enjoyment," to use Sedgwick's words, of Fred's physical beauty leads to a corrective punishment in accordance with the Christian teachings.

The confirmation that Dr. Saunders was really disturbed by Fred's beauty comes during their journey in the boat to Kanda-Meira Island. During this journey they had to go through a bad weather with huge waves hurling against their boat almost leading it to the bottom of the sea. Of all the passengers on board, Dr. Saunders was the only one who was terrified, almost in panic. He could only relax after smoking opium. Then, while falling asleep, he felt as if the Captain was taking them into a different world. He was experiencing something similar to death. Next morning, the weather had changed entirely into calmness which had a relieving effect on Dr. Saunders's nerves. Such a relief makes him not only feel reborn but also leaves him unusually off-guarded. It is then, that after seeing Fred stark naked while having a shower, he feels at ease to compliment his beauty, something to which Fred reacts with indifference. In this situation, it should be also observed 
that obviously this time in his complement Dr. Saunders is not only referring to Fred's face, but especially to his body.

Later on, Dr. Saunders's admiration for Fred goes a little deeper. He recognizes that his beauty is not only physical, but also intellectual. He finds this out when he witnesses the conversation between him and Erik Christessen, the Danish boy whom they meet in Kanda-Meira. He then perceives how much he identifies with the Australian young man in terms of the way they see life. Both of them share the idea that by remaining quite one can always avoid surprises that can be rather shocking.

Actually, The Narrom Cormer is permeated with the idea that, in what concerns one's sexuality, more than shocking, not remaining quite could be fatal. As it turns out fatality is what is meant for those who cannot remain quite in face of Fred Blake's beauty. This is the outcome of his involvement with Louise, Erik's fiancée. When Erik catches him leaving her bedroom furtively in the middle of the night, he commits suicide, apparently disappointed with the betrayal of both his beloved and his best friend. Shocked with this incident, Fred tells Dr. Saunders the reason of his leaving Australia also in a furtive way. It has to do with his sexual involvement with a married woman, a certain Mrs. Hudson who, willing to oblige Fred to stay with her, plans her husband's discovery of their love affair. Having been caught by Mr. Hudson, they have a fight that ends up in the husband's accidental death. Later on, it is Mrs. Hudson who commits suicide on knowing that she will no longer see Fred again. So, the deaths of these three people are indirectly caused by Fred's physical beauty. No doubt, Fred works here as an inversion of the figure of the femme fatale, the woman whose beauty and power of seduction can lead men into destruction. In his own case, Fred's beauty might have eventually provoked his own destruction since by the end of the novel we do not know exactly what happens to him after having dived overboard.

But all this apology of Fred's beauty is not the only homosexual trace we can find in The Narrow Corner: Returning to the character of Dr. Saunders, it is also an evidence of the construction of a homosexual character the way he reacts to women, in this specific case to Louise, the only female character in the story with whom he interacts. When she first ap pears in the novel, the narrator uses the situation to reveal Dr. Saunders's reaction to her beauty and his view of feminine beauty in general. This is what the narrator says on this respect:

The doctor was not as a rule captivated by feminine beauty; he could not but think the manner in which a woman's frame was made for obvious physiological 
purposes much detracted from its aesthetic appeal. Just as a table should be solid, of a convenient height and roomy, so a woman should be large-breasted and broad in the beam; but in both cases beauty could only be an adjunct to utility. You might say that a table which was solid, roomy, and of a convenient height was beautiful, but the doctor preferred to say that is was solid, roomy, and of a convenient height. (Narrow, 121).

Still in his appraisal of the girl, Dr. Saunders is reminded "of some statue he had seen in a museum of a goddess attaching her peplum; he could not remember it very exactly. Greco-Roman, he thought" (Narrow, 121). This comparison of the girl with a statue is not gratuitous. After defining feminine beauty as just "an adjunct to utility," with this new comparison, Dr. Saunders moves a step further from any appreciation of feminine beauty. It should be noticed that his comparison is full of vagueness and indefiniteness. The girl reminds him of "some statue." He cannot name it. And he saw it "in a museum" that again is not named. With this attitude, there is a reinforcement of his indifference towards feminine beauty.

But his distancing from feminine beauty still goes a step further away in this scene. The girl's slenderness reminds him of some little Chinese girls, "in whose company in his younger days he had on occasion passed moments of somewhat detached amusement" (Narrow, 121). In this quotation, two pairs of words are especially significant: "younger days" and "detached amusement". The first carries out the idea that Dr. Saunders's indifference to feminine beauty, or better say, to women in general, has nothing to do with age. After all, it could have been assumed that his present indifference is a consequence of his being a middle-aged man who is already satisfied with his experiences with the opposite sex. Completing this first assumption, the second pair of words carries out the idea that whatever the involvement he had with women in his youth, it was of a detached nature. There was no deep and significant emotional involvement.

Following this non-flattering introduction of Louise, she develops into a negative element in the story by becoming the reason for the breaking up of the almost perfect friendship between Fred and her fiancée Erik. Seduced by the former's beauty, she indulges in having sex with him who was ignorant of her engagement to his friend. The consequence is Erik's suicide and Fred's determination of never seeing her again. 
Contrasting to the negativity of Louise's presence, there is the idealization of the friendship between Fred and Erick who, in Richard Calder's words, "is the personification of idealistic goodness." (Calder, 1972) In this sense, it is interesting to notice the great emphasis given to the value Fred attributes to this friendship. He leaves no room for doubt about his greater respect, admiration, and love for his friend. Learning that he and Louise were engaged, Fred confesses he would have never slept with her if he knew she was Erik's girl. He says to Dr. Saunders:

... She meant nothing to me, really. If I'd only known I wouldn't have thought of fooling about with her. He was the best pal a chap ever had. I wouldn't have hurt him for anything in the world. What a beast he must have thought me! He'd been so awfully decent to me. (Narrow, 173)

Two things should be concluded from this episode. First of all, there is a clear intention of depicting Louise, the only female character in this love triangle, as morally inferior to both Erik and Fred. In spite of her commitment to Erik she yields to Fred's insistence in having sex with her, an attitude which reminds us that of Mrs. Hudson's. Secondly, as Fred makes clear in his conversation with Dr. Saunders after finding out about Erik's suicide, he values his friendship more than a sexual or emotional involvement with Louise. Had he known they were engaged, he would have not given vent to his sexual desire for her.

Apart from the outcome of their relationship, it should be noticed that there is an intention of depicting this friendship between those two men as being almost perfect. In a way, we can say that one completes the other. Fred is a handsome boy who thinks that life can only have meaning when one has enough money to enjoy the pleasures it offers. Erik is an unattractive, romantic and idealist boy who loves reading and reciting Shakespeare. We see that where the former could only see the ruins of an old Portuguese fort, the latter could see the story of many men who left their country to build an empire with possessions all over the world. Where the former could only see a girl who aroused his sexual desires, the latter could see the embodiment of perfection, a being from the fairy-tale world.

We are not told the way Erik sees his friendship with Fred. But it can be deduced from the way he reacts when he finds out his friend had slept with Louise that he reciprocates it. Possessed with rage, he first attacks the man whom he sees leaving Louise's bedroom. In a second moment, realizing it was 
Fred, he just puts him aside and goes away and, as we find out later, commits suicide. Due to his romantic and idealistic personality it would be incoherent to expect a violent attitude of Erik such as killing either Fred or Louise. However, we can suppose that if it had been another man he caught with Louise he probably would have not committed suicide. His tragic attitude leads us to conclude that his fatal act was motivated equally by his disap pointment with Louise as well as his disappointment with Fred and that the intensity of his feeling for Fred is at least at the same level of his love for Louise.

With so many obvious homoerotic elements in his novel, one wonders, as it is suggested by his biographers, how cautious Maugham really was in keeping homosexuality out of The Narrow Corner. If it is true that he always kept this determination, it is evident that in his development of this novel, and especially in the development of his characters, Dr. Saunders becomes completely independent of his creator's intention. Perhaps, Maugham's definition of his own creation process might help us understand this contradiction. For him, writing worked as a catharsis to get rid of any painful experience of the past. The best example of this is the initial scene of his masterpiece Of Human Bondage where he describes the pains of an eight-yearold boy who looses his mother. This scene, as Maugham himself confesses, was created as an attempt to overcome the painful loss of his own mother which he experienced when a small boy.

In this perspective, the creation of Dr. Saunders with so many obvious homosexual traits can be interpreted as Maugham's attempt at a catharsis of his own suffering as a homosexual man or, at least, an attempt at a better understanding of his own sexuality. For obvious reasons, he could have not created an overtly gay character.

Supporting this view, there are several points in common between Dr. Saunders and his creator. The most obvious one is the fact that he is a doctor, what was also Maugham's qualification although he never practiced it. Secondly, there is the fact that Dr. Saunders lives in self-exile. During most of his life, Maugham was always traveling abroad and finally settled down in France where he lived until his death. Still in relation to this self-exile situation, there is another similarity to be raised. It involves the reason of their exile which, in the case of Dr. Saunders is, as we have seen above, a supposition that is reinforced when we consider the facts of the life of his creator. In his above-mentioned article, Vidal says that Maugham's reasons for spending so much time abroad had not only to do with his search for new material for his 
fiction, as he always claimed, but also because of his two vices, which he calls $B \& B$, i.e., Bridge and Boys. Boys could be, then, the answer to the mystery that involves Dr. Saunders's reason for leaving England and living abroad, a mystery that is never revealed throughout the novel and is left open to the reader's speculation. Finally, the maintenance of this secret is in accordance with both Dr. Saunders's philosophy of life of remaining quite to avoid trouble and also to Maugham's own philosophy. This one, which he first expressed in his earlier masterpiece of Human Bondage dictates: "Follow your inclinations with due regard to the policeman round the corner."

\section{REFERENCES}

Calder, Robert Lorin. IV. Somerset Maugham and the Quest for Freedom London:

William Heinemann Ltd., 1972

Maugham, W. Somerset. Of Human Bondage. 1915. London: Mandarin Paperbacks, 1990.

Maugham, W. Somerset. The Narrow Corner. 1932. Middlessex: Penguin Book Ltd, 1967.

Morgan, Ted. Somerset Maugham. London: Jonathan Cape, 1980.

Sedgwick, Eve Kosofsky. Epistemology of the Closet. London: Penguin Book, 1994.

Spencer, Colin. Homossexualidade - Uma História. Trad. de Rubem Mauro Machado. Rio de Janeiro: Record, 1980.

Vidal, Gore. A View from the Diners Club - Essays 1987-1991. London: Andre Deutsch, 1991. 